\title{
Gamification Acceptance for Learners with Different E-Skills
}

\author{
Aliki Panagiotarou, Yannis C. Stamatiou and Christos Pierrakeas \\ University of Patras \\ Greece \\ Achilles Kameas \\ Hellenic Open University \\ Greece
}

\begin{abstract}
As gamification may benefit the learning experience, many Technology Acceptance Models affecting the user's acceptance of using gamification have been investigated. However, there has been limited work on the digital skills level and the adoption of user acceptance gamification. This paper examines the user's perceptions of gamification acceptance in e- learning environments. For this reason, a research model based on the Technology Acceptance Model (TAM) proposed to reveal the relationships between the constructs of the model and participants with different e-skills Level. The search data collected from 188 participants of a Massive Open Online Courses (MOOC) course focused on enhancing cybersecurity skills. Nonparametric tests and Structural Equation Modelling (SEM) implemented for the hypothesis tests. Findings prove that there are statistical differences among participants with different Level of e-skills on Perceived Usefulness (PU), Perceived Ease of Use (PEOU), Intention Use (IU) and Actual Use (AU). Also, the study reveals significant positive relationships among most of the model's constructs on gamification acceptance. The extra factor "ICT Level" provides a roadmap deeper understanding of the studies based on e-learning Technology Acceptance Models and show that affect the adoption of user acceptance.
\end{abstract}

Keywords: Gamification; Technology Acceptance Model; ICT skills; Structural Equation Modelling; ICT skills; e-learning

\section{Introduction}

It is well acknowledged in many types of research that the adoption of the effectiveness of e-learning could achieve a much better learning performance either independently or in a complementary way to the educational process (Fokides, 2017; Serdyukov, 2017). So, many educational organizations are in this direction and they provide as many as online courses (Rajabalee, Santally, \& 
Rennie, 2019; Vlachopoulos \& Makri, 2017). However, there are still many issues regarding the use of appropriate methods and learning tools to achieve the desired motivation and dedication of learners (Moghavvemi, 2015). For this reason, a massive array of different digital learning environments (tools) has been implemented and evaluated in diverse learning environments. Those tools increase engagement, motivation, achievement and retention while at the same time improving personal learning and thinking skills (Abrahim, Mir, Suhara, Mohamed, \& Sato, 2019). Besides, it can enchance the quality of teaching and increase digital literacy (Krasna \& Bratina, 2010, 2012).

According to Hamari \& Koivisto (2013), the improvement of digital literacy through Massive Open Online Courses (MOOC) is a high priority in many countries, including Greece ( Nikolaidis, Nath, Procaccia, \& Srinivasa., 2017). MOOCs are open educational platforms that provide online courses without any previous knowledge or experience on ICT except Internet Access (Al-Shabandar, Hussain, Liatsis, \& Keight, 2018; Al-Rahmi, Aldraiweesh, Yahaya, Bin Kamin, \& Zeki., 2018; Castaño-Muñoz, Kalz, Kreijns, \& Punie, 2018). There are educational tools that used in courses, including video lectures, weekly quizzes, regular assessments and even documents. Learners have proved this in beneficial collaboration by using asynchronous discussion forums (Bogdanova \& Snoeck, 2018).

In recent years, the systematic use of gamification has been evolved into a highly popular learning tool, integrated into many information systems. This activity also reflected in the continued growth researches involved in the study of the gamification phenomenon, that focus mainly on designing modules and learning activities during e-learning procedure (Giannakos, 2013; Varannai, Sasvari, \& Urbanovics, 2017). The main objective of Gamification in Education is to increase the motivation and engagement of learners to improve their skills when engaging in e-learning activity (Koivisto \& Hamari, 2019; Woo, 2014). In this context, the use of gamification in the educational environments can be a good solution and show that the user can produce the desired results (Fokides, Atsikpasi, Kaimara, \& Deliyannis., 2019; Fokides, 2017; Sánchez-Mena, MartíParreño, \& Aldás-Manzano, 2018). So, recently research interest has focused on developing standardized and modularized curriculums, applying many methodologies, albeit on a theoretical level. In educational contexts, researchers investigated the effects of game elements and found that they motivated students to go further in their lessons and thus improve learning outcomes (Hamari, Koivisto, \& Sarsa., 2014). Most games are built as simulations of some real-world situation or hypothetical situation that have similarities to the real world. Moreover, gamification provides feedback to measure players' growth towards outcomes, while the players can influence progress by their actions and overall strategies of play (Bayerl, Davey, Lohrmann, \& Saunders., 2019).

Until now, there are a variety of previous studies about (e-learning) technology acceptance of learners. These studies adapted in popular models and theories such as TAM Technology Acceptance Model (Davis, 1989), Technology Acceptance Model 2 (TAM2) (Venkatesh \& Davis, 2000) and Technology Acceptance Model 3 (TAM3) (Venkatesh \& Bala, 2008). Theory of Reasonable 
Action (TRA) (Ajzen \& Fisbein, 1980), Theory of Planned Behavior (TPB) (Ajzen, 1985), Unified Theory of Acceptance and Use of Technology (UTAUT) (Venkatesh, Morris, Davis, \& Davis, 2003) and show the user attitude of using technology in the presence of different factors. These factors, such as characteristics of learners or characteristics of the system, influence the technology acceptance. In this context, many models can be unified and further extended using external factors. Those models have been proved that affect the user e-learning acceptance denotes as "computer self-efficacy", "computer anxiety", "prior experience", "enjoyment", "learning motivation", "perceived learnability", "Hedonic Motivation", "personal innovativeness" and "student engagement" (Esteban-Millat, Martínez-López, Pujol-Jover,. Gázquez-Abad \& Alegret, 2018; Tarhini, Hone, \& Liu, 2013; Liu, Chen, Sun, Wible, \& Kuo, 2010; Tan \& Hsu, 2018; Wu, \& Chen 2017). A variety of studies in the gamification acceptance model are explored in detail in the literature review section.

This paper organized as follows: In section 2, firstly, related work about Gamification acceptance is shown and secondly, propose a research model for gamification acceptance in an e-learning environment. Section 3 describes the eskill construct and the hypotheses tests. Section 4 outlines the methodology including Descriptive statistics, Validity and Reliability of constructs and in Section 5 describes the Data Analysis. In Section 6, the results are discussed and finally, Sections 7, 8, 9 provides the conclusions, recommendations and implications.

\section{Literature Review}

A. Related Work

In this section, we gathered a summary of previous works in learner's perceptions of gamification acceptance models. These works clarified in four columns: a) the theory based on b) the factors used c) the external variables added and d) the linked-reference as show the table 1 :

Table 1: Gamification acceptance models

\begin{tabular}{|c|c|c|c|}
\hline Theory that used & Factors & Extra Factors & Reference \\
\hline TPB & $\begin{array}{lc}\text { Social influence, } \\
\text { Attitude, continued } \\
\text { use intention, } \\
\text { intention to use }\end{array}$ & \begin{tabular}{lr}
\multicolumn{2}{l}{ Recognition, } \\
perceived reciprocal \\
benefits, network \\
exposure
\end{tabular} & $\begin{array}{lr}\text { (Ajzen, } & 1985 ; \\
\text { Venkatesh } & \text { \& } \\
\text { Bala, 2008 } & \end{array}$ \\
\hline TAM 2 & $\begin{array}{l}\text { Behavioural } \\
\text { intention to use, } \\
\text { Subjective norm, } \\
\text { Perceived usefulness, } \\
\text { Perceived ease of use }\end{array}$ & $\begin{array}{lr}\text { Curiosity, } & \text { Joy, } \\
\text { Control } & \text { Focused } \\
\text { immersion } & \end{array}$ & $\begin{array}{l}\text { Oluwajana, } \\
\text { Vanduhe, Idowu, } \\
\text { Cemal Nat, \& } \\
\text { Fadiya, 2019; } \\
\text { Venkatesh \& } \\
\text { Davis, 2000) }\end{array}$ \\
\hline TAM & $\begin{array}{l}\text { Perceived usefulness, } \\
\text { Perceived ease of use, } \\
\text { Behavior Intension }\end{array}$ & $\begin{array}{l}\text { Telepresence, Flow, } \\
\text { Interactivity, } \\
\text { Enjoyment, Content } \\
\text { Interface }\end{array}$ & $\begin{array}{l}\text { (Davis, 1989; } \\
\text { Herzig, } \\
\text { Strahringer,\& } \\
\text { Ameling., 2012) }\end{array}$ \\
\hline UTAUT2 & $\begin{array}{ll}\text { Performance } & \\
\text { expectancy, } & \text { Effort } \\
\text { Expectancy, } & \text { Social }\end{array}$ & Gamification impact & $\begin{array}{lr}\text { (Baptista } & \& \\
\text { Tiago., } & \text { 2017; } \\
\text { Venkatesh, } & \end{array}$ \\
\hline
\end{tabular}




\begin{tabular}{|c|c|c|c|}
\hline & $\begin{array}{l}\text { influence, Facilitating } \\
\text { conditions, age and } \\
\text { gender, behavioural } \\
\text { intention, Hedonic } \\
\text { motivation, Price } \\
\text { value, Habit }\end{array}$ & & $\begin{array}{l}\text { Thong, \& Xu., } \\
\text { 2012) }\end{array}$ \\
\hline $\begin{array}{ll}\text { SLE } & \text { Research } \\
\text { Model } & \end{array}$ & $\begin{array}{lr}\text { content, technical } \\
\text { features, user state of } \\
\text { mind, learning } \\
\text { enabling features }\end{array}$ & - & $\begin{array}{l}\text { (Fokides et al., } \\
\text { 2019) }\end{array}$ \\
\hline TRA- TAM & $\begin{array}{l}\text { Behavioural } \\
\text { intention to use } \\
\text { technology, Attitude } \\
\text { toward use, } \\
\text { Perceived usefulness, } \\
\text { Perceived ease of use }\end{array}$ & Self Efficacy & 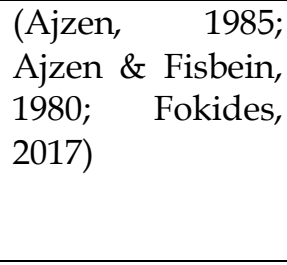 \\
\hline TAM & $\begin{array}{l}\text { The attitude of } \\
\text { Educational Video } \\
\text { games, Ease of use of } \\
\text { Educational Video } \\
\text { Games, Intention to } \\
\text { use Educational } \\
\text { video games, } \\
\text { Perceived usefulness } \\
\text { of Educational video } \\
\text { games }\end{array}$ & - & $\begin{array}{l}\text { (Davis, 1989; } \\
\text { Sánchez-Mena, } \\
\text { Martí-Parreño, \& } \\
\text { Aldás-Manzano., } \\
\text { 2016) }\end{array}$ \\
\hline $\begin{array}{l}\text { TAM, } \\
\text { Gamification } \\
\text { Acceptance } \\
\text { Model }\end{array}$ & $\begin{array}{l}\text { Gamification } \\
\text { Perceived } \\
\text { Usefulness, } \\
\text { Gamification of Ease } \\
\text { to use, Attitude } \\
\text { Towards using } \\
\text { gamification }\end{array}$ & Student Engagement & $\begin{array}{l}\text { (Davis, 1989; Ab. } \\
\text { Rahman, } \\
\text { Ahmad, \& } \\
\text { Hashim, 2018) }\end{array}$ \\
\hline TAM & $\begin{array}{l}\text { Perceived usefulness, } \\
\text { Perceived ease of use, } \\
\text { Attitude, Intention }\end{array}$ & $\begin{array}{l}\text { Experience, } \\
\text { Availability }\end{array}$ & $\begin{array}{l}\text { (Davis,1989; } \\
\text { Varannai, et al., } \\
\text { 2017) }\end{array}$ \\
\hline TAM & $\begin{array}{l}\text { Intention to Use the } \\
\text { Educational Game }\end{array}$ & $\begin{array}{l}\text { Enjoyment, } \\
\text { Happiness, } \\
\text { Performance }\end{array}$ & $\begin{array}{l}\text { (Davis,1989; } \\
\text { Giannakos, 2013) }\end{array}$ \\
\hline
\end{tabular}

B. The constructs of the proposed model

As can be seen from the table above, the original TAM fits for this study. So, the basis of the new proposed model relies on its basic constructs which are Perceived Usefulness (PU), Perceived Ease of Use (PEOU), Intention to Use (IU) and Actual Use (AU). As concerns, the additional constructs, the meaning of Perceived Self Efficacy (PSE) is the degree of self-confidence in the ability to complete a task. Many studies have proven that a higher Self Efficacy enhances productivity using an information system (Chao C. M., 2019; Fokides, 2017; Fathema, Shannon, Ross, 2015; Moghavvemi, 2014). Thus, the meaning of Perceived Learnability (PL) would be how someone understands, learns and remembers using an application. According to Hu \& Hui (2011) and Stiles- 
Shields et al. (2017), someone with a higher Perceived Learnability believes that using an information system improves his or her performance. Finally, the Fun and Reward (FUN) construct measures the enjoyment of using educational games (Giannakos, 2017; Wang \& Chuen-Tsai, 2012) and is expected to affect the proposed model.

\section{Theoretical model construct-ICT-skills}

Digital skills exist on a spectrum, from basic to more advanced, and encompass a "combination of behaviours, expertise, know-how, work habits, character traits, dispositions and critical understandings." (Unesco, 2017). So, previous works examined factors denoted as computer self-efficacy (Abdullah, \& Ward, 2016; Liu, 2010), IT experience (Brezavšček, Šparl, \& Žnidaršič., 2014; Cheng, Wang, Moormann, Olaniran, \& Chen, 2012), Perceived digital competence (Callum, Jeffrey, \& NA, 2014), computer anxiety (Al-Gahtani, 2016; Schlag \& Imhof, 2017) Digital competence (Kim, et al., 2018; Stephan, Markus, \& Gläser-Zikuda, 2019). However, all the items used to create the above constructs are restricted and insufficient in the context to investigate the digital skills of learners (usually a maximum of 3-5 items examined). So, the items that used must be enriched and redefine. This gap comes to close a framework, named DigComp (Carretero, Vuorikari, \& Punie, 2017), and define what does mean digital competency and is an appropriate tool for self-assessment tool and present successful approaches for improving basic and intermediate skills (Panagiotarou, Vasiliadis \& Kameas., 2019). The digital profile of participants of this course is examined based on the European digital competences' framework (Ikanos, 2019). Categorizing participants relative to the digital skills level, used a 10-point Likert scale to give more variance and a higher degree of measurement accuracy. Participants classified into three categories: Basic, Intermediate and Advanced Level.

D. A Proposed Research Model

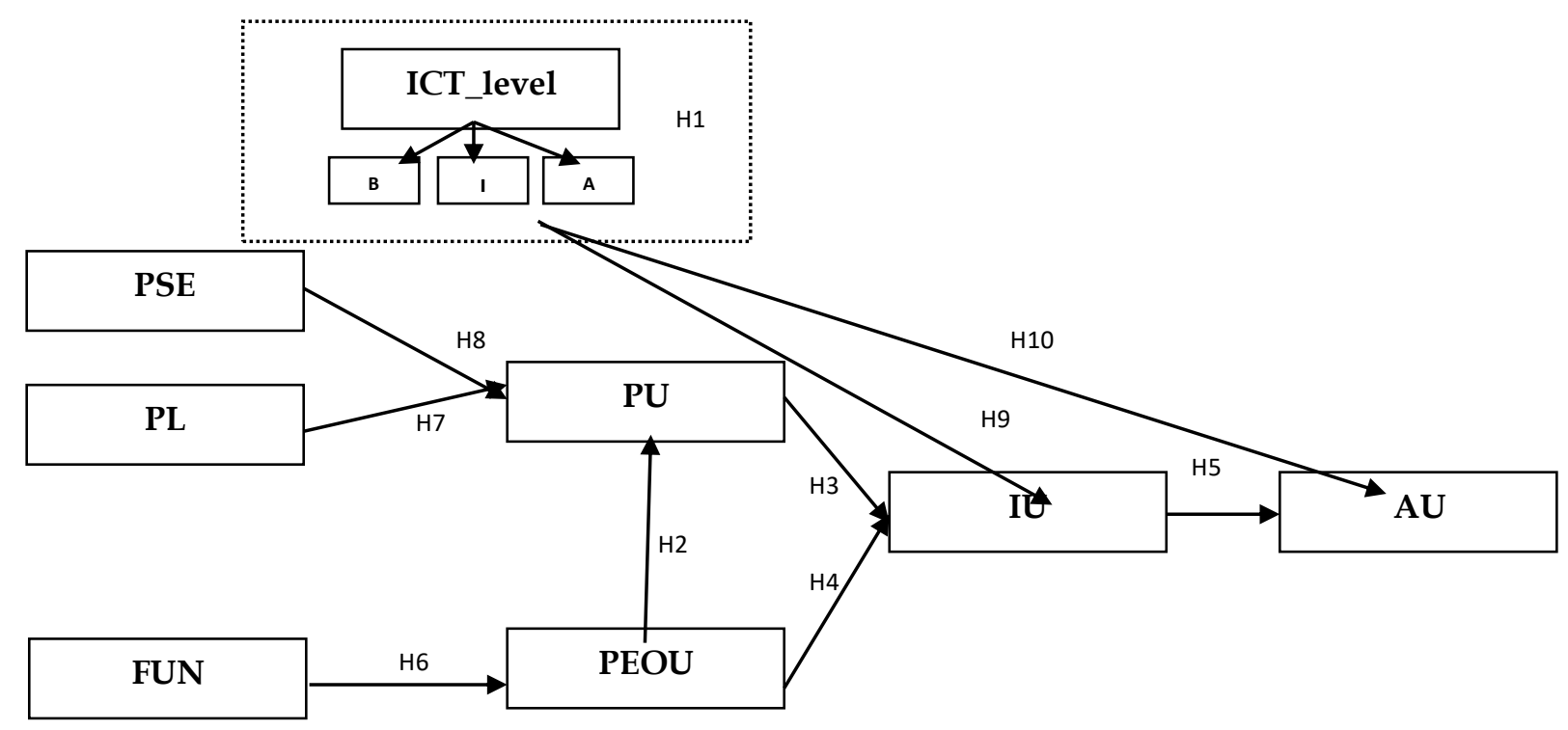

Figure 1: A proposed Research Model 
This paper proposes a model based on factors of past related works according to TAM and providing mainly the relationship between constructs of TAM and ICT Level group. (figure 1). Based on the review of the literature, further relationships among these constructs of the proposed model examined investigating the adoption of gamification.

\section{Hypotheses Tests}

Hypothesis tests described below:

A. Firstly, the first hypothesis test investigates to what extent the adoption of gamification is influenced by the e-skills Level of participants.

H1: There are statistically significant differences between PU, PEOU, IU, AU, PSE, PL, FUN between Basic, Intermediate and Advanced Level of e-skills

\section{B. Additional Hypotheses tests}

The following assumptions investigate the relationships among constructs of TAM:

H2: PU has a significant effect on PEOU

H3: PU has a significant effect on IU

H4: PEOU has a significant effect on IU

H5: IU has a significant effect on AU

H6: FUN has a significant effect on PEOU

H7: PL has a significant effect on PU

H8: PSE of gamification has a significant effect on PU of gamification in learning

H9: Level of ICT skills has a significant effect on IU of gamification in learning

H10: Level of ICT skills has a significant effect on AU of gamification in learning

\section{Method}

To examine the acceptance of gamification in learning, a MOOC course was developed (Spyropoulou, Pierrakeas, \& Kameas., 2019) in a Moodle server of the research group- DAISSy- at Hellenic Open University (HOU) (DAISSy, 2001). This course aimed at improving internet safety skills. The learning activities include (1) texts, projects and game elements for student performance (2) interactive forum and multichoice test for feedback and assessment activities. Among the different types of game elements that offered (Vlachopoulos \& Makri, 2017) we choose to embed simulations type meaning that participants must achieve real-world problems. The author sent two online questionnaires in each participant, the first one included demographics and measured the Level of e-skills of participants and the second one measured the effectiveness of gamification technique for learner's engagement.

\section{A. Sample}

The sample of this study consisted of 188 participants in a MOOC course. Firstly, the course trailer shared on social media networks. The participants included different groups of social media that responded by a subscription. Two hundred fifty individuals' candidates applied for the course, but only 188 completed it. In overall, $101(53 \%)$ of the responders were female, and $87(47 \%)$ of them were male and according to their age $65(34 \%)$ of them were $20-30,35(18 \%)$ of them were 30 - 
$40,56(30 \%)$ of them were $>40$ and $32(17 \%)$ of them were $<20$. Hence, $88(47 \%)$ of the responders have three types of devices, $73(38 \%)$ of them have two types of the devices while just $27(14 \%)$ have one type of device. In the following figure (Figure 2) shows the participants that attended the e-learning course and how they gained their ICT knowledge.

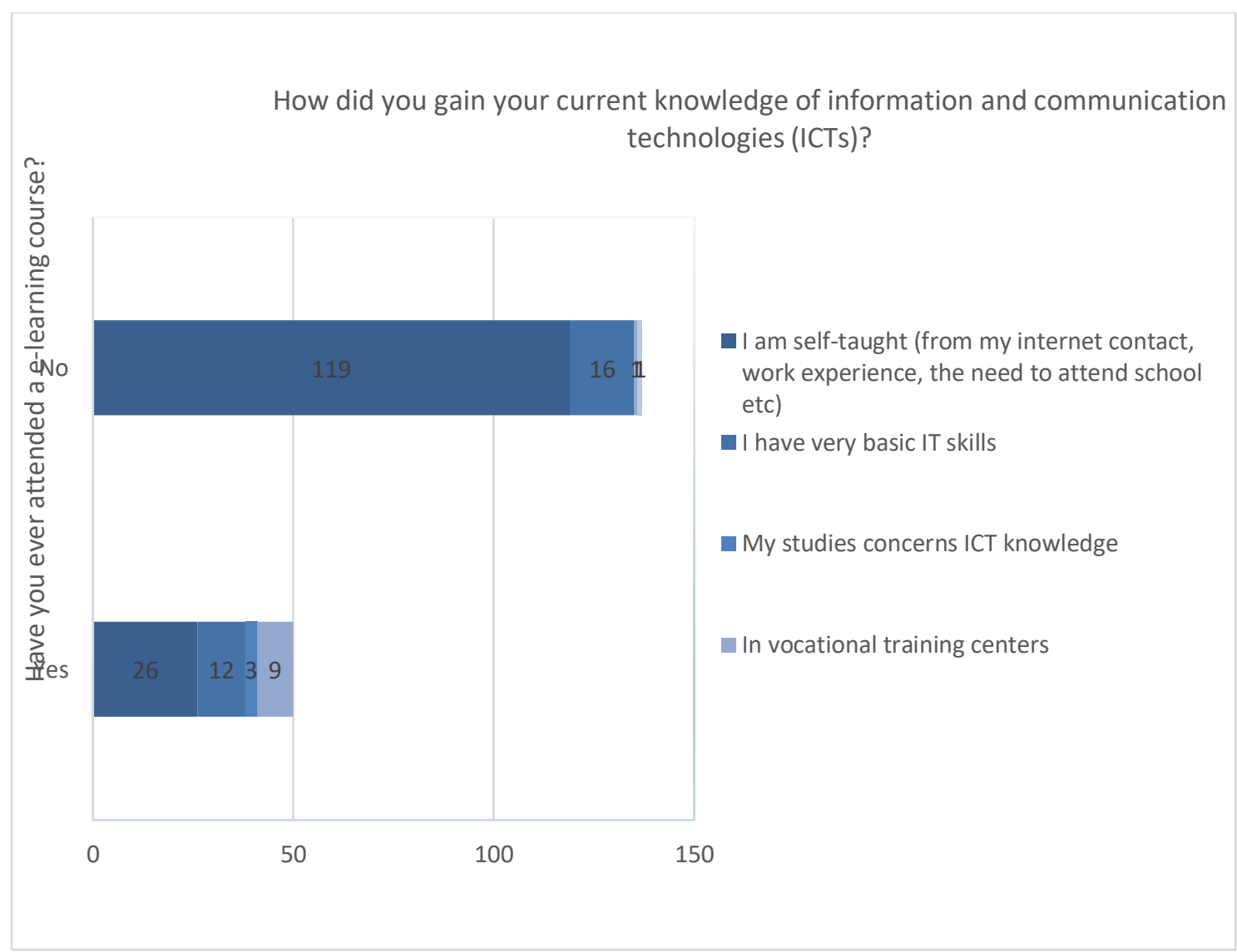

Figure 2: Attendance e-learning course/Digital knowledge gained

B. Validity and reliability of constructs

KMO Bartlett's test indicated the sampling adequacy of data for structure detection and showed that was suitable $(82,9 \%)$ for all the variables in the analysis. However, Confirmatory Factor Analysis (CFA) implemented for the validity of the questionnaire. All the constructs had Cronbach's alpha greater than 0.7 confirming their reliability. The indicator of reliability tested, and all factor loadings were higher than $0.7(p<0,01)$. Then, the convergent validity included the Average Variance Extracted (AVE) (where AVE was slightly below 0.5), and Composite Reliability (CR) were tested (results in Table 2). Both criteria were satisfied and ensure that all items demonstrate good construct reliability, good indicator reliability and good convergence validity. Finally, however, some of a set of indicators goodness of fit used to evaluate the overall fit of the model such as Standardized Root Mean Square Residual (SRMR), Related Fit Index (RFI), and Normed Fit Index (NFI) (Prudon, 2015; Abraham et al., 2019) (Table 3). All indicators support the goodness of fit of the model. 
Table 2: Validity and reliability of the constructs

\begin{tabular}{|c|c|c|c|c|}
\hline Items & $\begin{array}{l}\text { Cronbach's } \\
\text { Alpha }\end{array}$ & AVE & CR & Loadings \\
\hline PU1 & 0,723 & 0,472 & 0,830 & 0,715 \\
\hline PU2 & & & & 0,805 \\
\hline PU3 & & & & 0,758 \\
\hline PU4 & & & & 0,756 \\
\hline PEOU1 & 0,778 & 0,517 & 0,859 & 0,738 \\
\hline PEOU2 & & & & 0,743 \\
\hline PEOU3 & & & & 0,770 \\
\hline IU1 & 0,725 & 0,501 & 0,729 & 0,727 \\
\hline IU2 & & & & 0,701 \\
\hline IU3 & & & & 0,769 \\
\hline IU4 & & & & 0,723 \\
\hline AU1 & 0,786 & 0,669 & 0,865 & 0,915 \\
\hline AU2 & & & & 0,708 \\
\hline PSE1 & 0,720 & 0,468 & 0,862 & 0,727 \\
\hline PSE2 & & & & 0,708 \\
\hline PSE3 & & & & 0,739 \\
\hline PSE4 & & & & 0,544 \\
\hline PL1 & 0,812 & 0,530 & 0,889 & 0,832 \\
\hline PL2 & & & & 0,817 \\
\hline PL3 & & & & 0,851 \\
\hline PL4 & & & & 0,773 \\
\hline FUN1 & 0,809 & 0,552 & 0,797 & 0,901 \\
\hline FUN2 & & & & 0,783 \\
\hline
\end{tabular}

Table 3: Goodness of Fitness

\begin{tabular}{|l|l|l|}
\hline $\begin{array}{l}\text { The goodness of Fit } \\
\text { Indices }\end{array}$ & $\begin{array}{l}\text { Value (Saturated Model- } \\
\text { Estimated Model) }\end{array}$ & $\begin{array}{l}\text { The expected value for } \\
\text { Well-fitting model }\end{array}$ \\
\hline SRMR & $0.068-0.072$ & $<0.08$ \\
\hline RFI & $0.922-0.937$ & $>0.90$ \\
\hline NFI & $0.939-0.946$ & $>0.90$ \\
\hline
\end{tabular}

\section{Data Analysis}

A. One Way- ANOVA. As concerns hypothesis test $1(\mathrm{H} 1)$, nonparametric tests were implemented among participants with different Level of digital skills because data are not normally distributed. These groups are categorized as Basic, Intermediate and Advanced Digital Skills. Independent samples Kruskal Wallis test determined if there are statistically significant differences among different groups of digital skills Level for each factor of the model. The results 
showed that there are statistically significant differences of PU, PEOU and AU factors among different Level of digital skills. In contrast, there aren't statistically significant differences of IU, PSE, Pl and FUN factors among different Level of digital skills. (Figure 3). Post hoc tests confirmed the differences that occurred between groups, as seen in Figure 4, all pairwise comparisons show in which groups there are differences.

\begin{tabular}{|c|c|c|c|c|}
\hline \multicolumn{5}{|c|}{ Hypothesis Test Summary } \\
\hline & Null Hypothesis & Test & Sig. & Deoision \\
\hline 1 & $\begin{array}{l}\text { The distribution of PU is the same } \\
\text { across categories of Level_ICT. }\end{array}$ & $\begin{array}{l}\text { Independent- } \\
\text { Samples } \\
\text { Krubal. } \\
\text { Wallis Test }\end{array}$ & .000 & $\begin{array}{l}\text { Reject the } \\
\text { nuil } \\
\text { hypothesis. }\end{array}$ \\
\hline 2 & $\begin{array}{l}\text { The distribution of PEOU is the } \\
\text { same across categoties of } \\
\text { Level_ICT. }\end{array}$ & $\begin{array}{l}\text { Independent } \\
\text { Samples } \\
\text { Kruskal. } \\
\text { Wallis Test }\end{array}$ &, 000 & $\begin{array}{l}\text { Reject the } \\
\text { nuil } \\
\text { hypothesis. }\end{array}$ \\
\hline 3 & $\begin{array}{l}\text { The distribution of IU is the same } \\
\text { actoss categoties of Level_ICT. }\end{array}$ & $\begin{array}{l}\text { Independent- } \\
\text { Samples } \\
\text { Kruskat- } \\
\text { Wallis Test }\end{array}$ & .458 & $\begin{array}{l}\text { Retain the } \\
\text { null } \\
\text { hypothesis. }\end{array}$ \\
\hline 4 & $\begin{array}{l}\text { The distribution of AU is the same } \\
\text { across categories of Level_ICT. }\end{array}$ & $\begin{array}{l}\text { Independent- } \\
\text { Samples } \\
\text { Kruskal. } \\
\text { Wallis Test }\end{array}$ & .000 & $\begin{array}{l}\text { Reject the } \\
\text { nuli } \\
\text { hypothesis. }\end{array}$ \\
\hline 5 & $\begin{array}{l}\text { The distribution of PSE is the same } \\
\text { across oategories of Level_ICT. }\end{array}$ & $\begin{array}{l}\text { Independent- } \\
\text { eSamples } \\
\text { Kruskal: } \\
\text { Wallis Test }\end{array}$ & .394 & $\begin{array}{l}\text { Retain the } \\
\text { null } \\
\text { hypothesis. }\end{array}$ \\
\hline 6 & $\begin{array}{l}\text { The distribution of PL is the same } \\
\text { across categoties of Level_ICT. }\end{array}$ & $\begin{array}{l}\text { Independent- } \\
\text { Samples } \\
\text { Kruskal- } \\
\text { Wallis Test }\end{array}$ & .923 & $\begin{array}{l}\text { Retain the } \\
\text { null } \\
\text { hypothesis. }\end{array}$ \\
\hline 7 & $\begin{array}{l}\text { The distribution of FUN is the same } \\
\text { across categories of Level_ICT. }\end{array}$ & $\begin{array}{l}\text { Independent- } \\
\text { eSamples } \\
\text { Kruskal. } \\
\text { Wallis Test }\end{array}$ & .425 & $\begin{array}{l}\text { Retain the } \\
\text { null } \\
\text { hypothesis. }\end{array}$ \\
\hline
\end{tabular}

Asymptotic significances are displayed. The significance level is 05 .

Figure 3: One-way ANOVA results

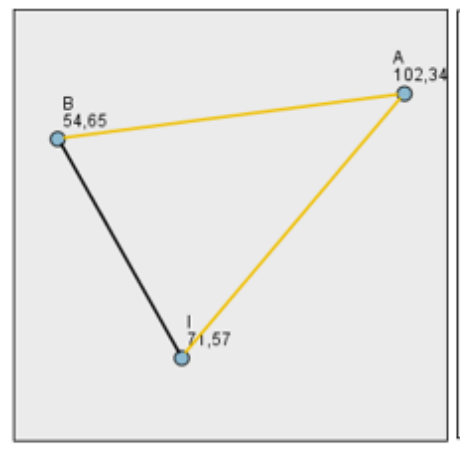

1.Pairwise comparison of PU and ICT level

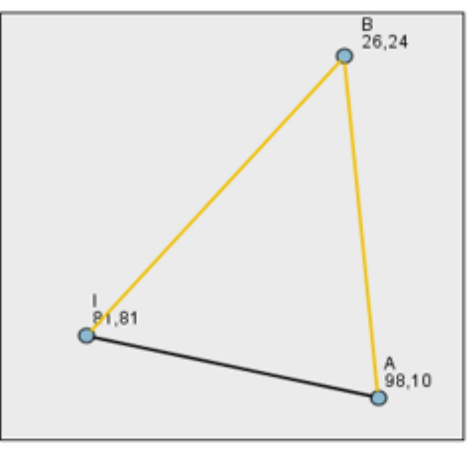

2.Pairwise comparison of PEOU and ICT level

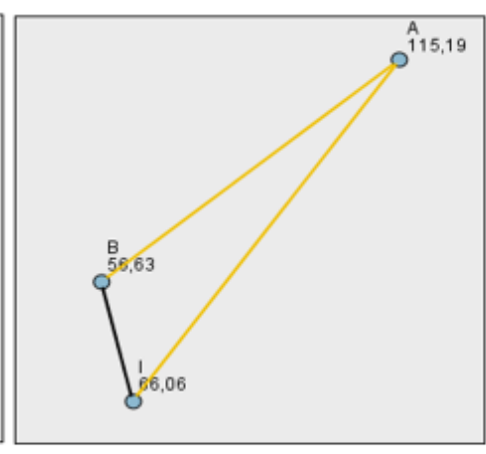

3.Pairwise comparison of Actual Use and ICT level

Figure 4: Pairwise comparisons in Post-Hoc Test

Each node shows the sample average rank of PU, PEOU and AU for each ICT level group. Each line tests the null hypothesis between-group distributions. (Orange lines show when rejecting the null hypothesis-show table 4-figure 4) $(\mathrm{p}<0.05)$. As shown in the first distance network of figure 4 , the differences in side effect score of Advanced level group vs Basic level group, as well, Advanced level group vs Intermediate level group are statistically significant 
and Basic level group vs Intermediate level group is not. The Advanced level group has a high effect score in PU than other groups. In the same way of explanation is displayed in the third distance network of figure 4 and the Advanced level group is displayed with high effect score in AU. Finally, regarding second distance network, the differences in side effect score of Basic level group vs Intermediate level group and Basic level group vs Advanced level group are statistically significant and Basic level group vs Advanced level group is not. The Basic level group has a profound effect score in PEOU than other groups.

B. Structure Equation Model (SEM). SEM was processed by using AMOS 21 software and examining the path coefficients between proposed hypotheses (H2H10). The purpose of SEM subjected to the multivariate technique that combines factor analysis and multiple regressions to simultaneously explore a series of interrelated dependence relationships among measured variables and latent variables as well as several latent constructs. The results indicated that Perceived ease of use $(\beta=0.3562, p<0.001)$ has a significant positive relationship on Perceived usefulness; Perceived usefulness has a positive relationship on Intention to Use $(\beta=0.240, p<0.05)$; Perceived ease of use $(\beta=0.236, p<0.05)$ also has a positive relationship on Intention to Use; Intention to Use has a significance positive relationship with Actual Use $(\beta=0.580, p<0.001)$; Fun has a significance positive relationship with Perceived ease of use $(\beta=0.388, p<0.001)$; Perceived Learnability has a positive relationship on Perceived usefulness $(\beta=0.413, p<0.05)$; ICT level has a positive relationship on Intention to Use $(\beta=0.150, p<0.05)$; ); ICT level has a significant negative relationship on Actual to Use $(\beta=-0.437, p<0.001)$. The results displayed in Figure 5 and Table 4.

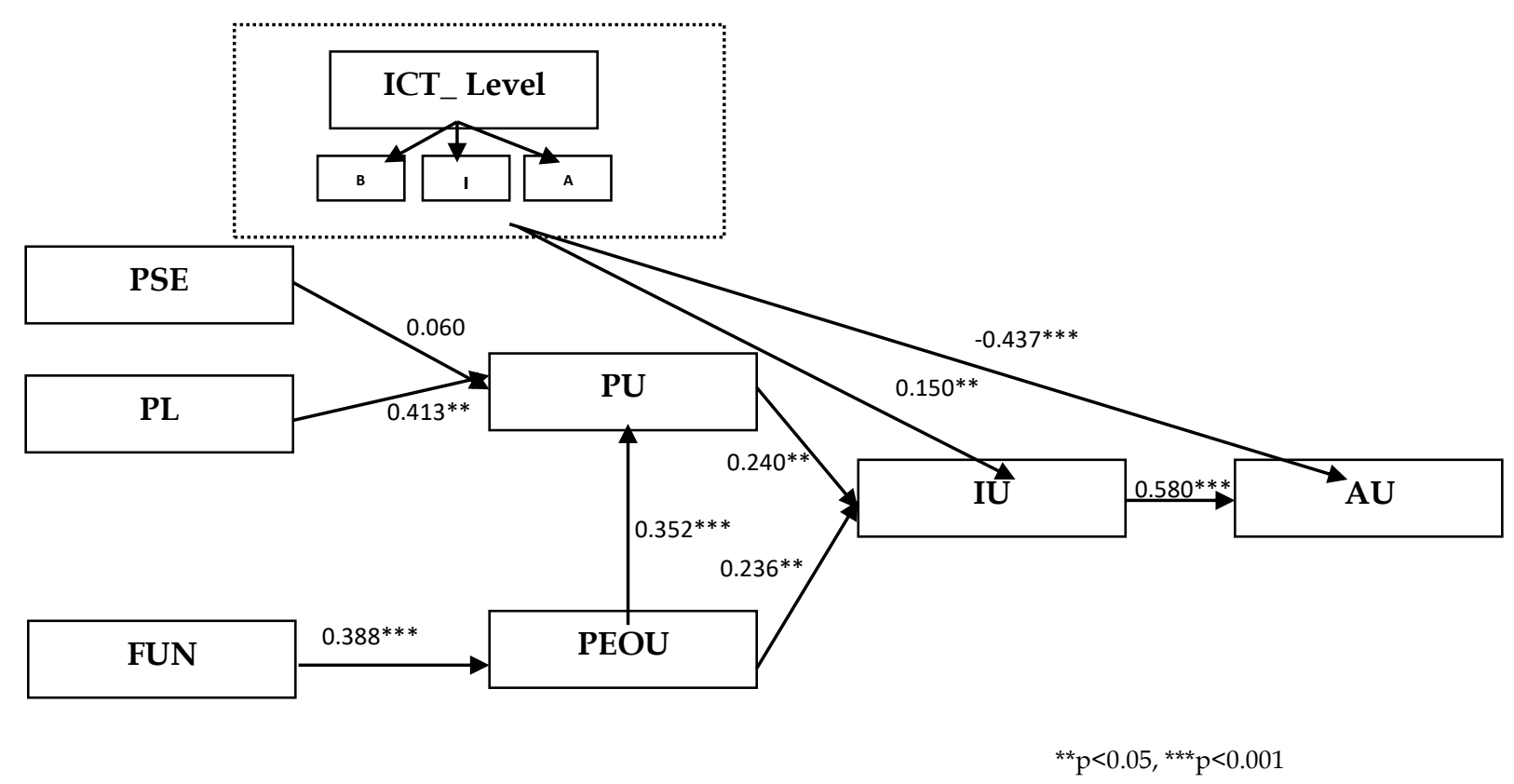

Figure 5: SEM results 
Table 4: Estimates and results of hypothesis

\begin{tabular}{l|lll}
\hline Hypothesis & Relationship & $\boldsymbol{\beta}$ (Estimate) & Result \\
\hline H2 & PEOU->PU & 0.352 & Supported $(\mathrm{p}<0.001)$ \\
H3 & PU->IU & 0.240 & Supported $(\mathrm{p}<0.05)$ \\
H4 & PEOU->IU & 0.236 & Supported $(\mathrm{p}<0.05)$ \\
H5 & IU->AU & 0.580 & Supported $(\mathrm{p}<0.001)$ \\
H6 & FUN->PEOU & 0.388 & Supported $(\mathrm{p}<0.001)$ \\
H7 & PL->PU & 0.413 & Supported $(\mathrm{p}<0.05)$ \\
H8 & PSE->PU & 0.060 & Not Supported \\
H9 & ICT_level->IU & 0.150 & Supported $(\mathrm{p}<0.05)$ \\
H10 & ICT_level->AU & -0.437 & Supported $(\mathrm{p}<0.001)$ \\
\hline
\end{tabular}

\section{Discussion}

A thorough identification of the participants level of digital skills investigated in this paper. The categorization of these groups based on a questionnaire with fifteen items. Hence, we had a bright appearance of the Level of ICT of Greek participants who most of them have never attended before an e-learning course $(72 \%)$. So, as we saw in Figure 2, most participants $(67 \%)$ had an intermediate level, and they are mostly self-taught $(77 \%)$. This study also developed a Gamification Acceptance model by adding ICT skills variable. This extra variable extended analysis by the different ICT level group and the fundamental factors of TAM. One of the significant findings is that the different ICT Level group sufficiently affects the factors of TAM.

In more detail, as concerns the $\mathrm{H} 1$ hypothesis significant differences there are among different ICT level groups on factors Perceived Usefulness, Perceived Ease of Use and Actual Use (Figure 3).In detail, as concerns Perceived Usefulness, participants with advanced ICT Level had higher perceived usefulness(represents high average ranks) in comparison to the other participants with Intermediate and Basic ICT level (lower average ranks). Then, there are no significant differences between the advanced ICT level group and the intermediate ICT level group on Perceived Ease of Use, (both exhibit high average ranks) in comparison to the Basic ICT level group. Lastly, regarding the Actual Use on advanced ICT level group, it differs significantly from the other groups (represents quite high average ranks) as seen in Figure 4. This means that users with an Advanced ICT level are more likely to accept the Usefulness, Ease of Use, and the actual use of a digital game for educational purposes.

The hypothesis tests (H2-H5) has shown that the impact of fundamental TAM factors, namely Perceived Usefulness, Perceived Ease of Use, Intention to Use and Actual Use of gamification has a positive effect (Abdullah \& Ward, 2016; AlShabandar, et al., 2018; Bogdanova \& Snoeck, 2018; Bayerl et al., 2019; EstebanMillat et al., 2018). Also, the Perceived Learnability and Fun and Reward factors found to positively affect usefulness (H7) and ease of use gamification (H6). As concerns in H8, Perceived Self-Efficacy was found not to be significantly related to people's Perceived Usefulness with the gamification. Finally, the results show that the participants who have different ICT level intent to use gamification (H9) 
in the e-learning environment but only participants with advanced ICT level group in actual use (H10). Moreover, the Gamification Acceptance Model proved that provided strong evidence that fits in the Greek sample.

\section{Conclusion}

In a rapidly evolving world, digital technologies are continuously growing, which means that it has a significant impact on the digital economy, productivity and innovation (Caena \& Redecker, 2019). Thus, digital technologies have modified the value and role of learning and teaching. Learning requires, among other things, great variety and flexibility in the ways and processes of learning, which ICTs offer as they can, inter alia, adapted to everyone's personal needs and cognitive needs (Ministry of Administrative Reconstruction, 2019). Both the Action Plan of the European Commission (January 2018) and the National Strategy of Greece aim, besides, at the digital readiness of educational organizations, the development of digital skills and the improvement of data analysis training (as cited Brolpito, 2018) emphasis on creating MOOC courses. The open education platforms and distance learning courses that offered in Greece through MOOCs are scarce according to a study by Panagiotarou \& Stamatiou (2019). So, to provide good e-learning practices through MOOC lessons, the author designed a standard MOOC lesson that contained a variety of different interactive activities, including gamification aimed at improving cybersecurity skills. Thus, the author measured the adoption of gamification through questionnaire and the results found that: Although there has been a positive impact on the acceptance of gamification in the e-learning environment, there are significant differences in the actual use by participants with a different digital background. So, it might be reasonable to conclude that learners must acquire digital knowledge and skills to enable them to effectively use ICT applications in education, improving their knowledge, skills, competences and upgrading their qualifications.

\section{Recommendations}

The proposed model could be applicable for the adoption of a broader range of digital tools in education such as m-learning, social media and, OER platform etc. and may reveal additional useful information about the user's acceptance in a various focus group, as students, teachers, lecturers, learners etc. Future research should explore practices for MOOCs design, game elements, implementation and evaluation with additional assumptions in socially different contexts and countries. Finally, this study could be a potential value for many previous and future works based on Technology Adoption Models studying the relationship between different factors and the Level of ICT skills.

\section{Implications and Limitations}

This study has its limitations. The sample is not large enough to represent the population of Greece. The questionnaire only applied to someone who had completed all the sections of the course, so those who did not complete the course could not participate in the survey. Also, the sample is based on Greek users and may be different in other countries. 


\section{References}

Abrahim, S., Mir, B. A., Suhara, H., Mohamed, F. A., \& Sato, M. (2019). Structural equation modelling and confirmatory factor analysis of social media use and education. International Journal of Educational Technology in Higher Education, 16(1). doi:10.1186/s41239-019-0157-y

Ab. Rahman, R., Ahmad, S., \& Hashim, U. R. (2018). The effectiveness of gamification technique for higher education student's engagement in polytechnic Muadzam Shah Pahang, Malaysia. International Journal of Educational Technology in Higher Education, 15(1). doi:10.1186/s41239-018-0123-0

Abdullah, F., \& Ward, R. (2016). Developing a General Extended Technology Acceptance Model for E-Learning (GETAMEL) by analysing commonly used external factors. Computers in Human Behavior, 56, 238-256. doi:10.1016/j.chb.2015.11.036

Ajzen, I. (1985). From Intentions to Actions: A Theory of Planned Behavior. Action Control, 11-39. doi:10.1007/978-3-642-69746-3_2

Ajzen, I., \& Fishbein, M. (1980). Understanding attitudes and predicting social behaviour. Englewood Cliffs, NJ: Prentice-Hall.

Al-Gahtani, S. (2016). An empirical investigation of e-learning acceptance and assimilation: A structural equation model. Applied Computing And Informatics, 12(1), 27-50. doi :10.1016/j.aci.2014.09.001

Al-Rahmi, W., Aldraiweesh, A., Yahaya, N., Bin Kamin, Y., \& Zeki, A. M. (2019). Massive Open Online Courses (MOOCs): Data on higher education. Data in Brief, 22, 118125. doi:10.1016/j.dib.2018.11.139

Al-Shabandar, R., Hussain, A. J., Liatsis, P., \& Keight, R. (2018). Analyzing Learners Behavior in MOOCs: An Examination of Performance and Motivation Using a Data-Driven Approach. IEEE Access, 6, 73669-73685. doi:10.1109/access.2018.2876755

Baptista, G., \& Oliveira, T. (2017). Why so serious? Gamification impact the acceptance of mobile banking services. Internet Research. 27. 118-139. doi:10.1108/IntR-10-20150295.

Bayerl, P. S., Davey, S., Lohrmann, P., \& Saunders, J. (2019). Evaluating Serious Game Trainings. Security Informatics and Law Enforcement, 149-169. doi:10.1007/978-3030-29926-2_9

Brolpito, A. (2018) Digital Skills and Competence, and Digital and Online Learning (Rep.). Turin, Italy: European Training Foundation.

Bogdanova, D., \& Snoeck, M. (2018). Using MOOC technology and formative assessment in a conceptual modelling course. Proceedings of the 21st ACM/IEEE International Conference on Model-Driven Engineering Languages and Systems Companion Proceedings - MODELS '18. doi:10.1145/3270112.3270120

Brezavšček, A., Šparl, P., \& Žnidaršič, A. (2014). Extended Technology Acceptance Model for SPSS Acceptance among Slovenian Students of Social Sciences. Organizacija, 47(2), 116-127. doi: 10.2478/orga-2014-0009

Caena, F., \& Redecker, C. (2019). Aligning teacher competence frameworks to 21st century challenges: The case for the European Digital Competence Framework for Educators (Digcompedu). European Journal of Education. doi:10.1111/ejed.12345

Carretero, S., Vuorikari, R., \& Punie, Y. (2017). DigComp 2.1: The Digital Competence Framework for Citizens with eight proficiency levels and examples of use, EUR 28558 EN. doi:10.2760/38842

Castaño-Muñoz, J., Kalz, M., Kreijns, K., \& Punie, Y. (2018). Who is taking MOOCs for teachers' professional development on the use of ICT? A cross-sectional study from Spain. Technology, Pedagogy and Education, 27(5), 607-624. doi:10.1080/1475939x.2018.1528997 
Chao, C.-M. (2019). Factors Determining the Behavioral Intention to Use Mobile Learning: An Application and Extension of the UTAUT Model. Frontiers in Psychology, 10. doi:10.3389/fpsyg.2019.01652

Cheng, B., Wang, M., Moormann, J., Olaniran, B., \& Chen, N. (2012). The effects of organizational learning environment factors on e-learning acceptance. Computers E Education, 58(3), 885-899. doi: 10.1016/j.compedu.2011.10.014

Ikanos. (2019). Citizen. Digital Competences Test. Free Access Retrieved 11 October 2019, from https:/ / test.ikanos.eus/index.php/566697? newtest=Y\&lang=en

Davis, F. D., (1989). Perceived usefulness, perceived ease of use, and user acceptance of information technology. MIS Quarterly (13), 319-339.

Daissy research group. (2001). Daissy -About. Retrieved February 1, 2020 from http://daissy.eap.gr/en/about/

Esteban-Millat, I., Martínez-López, F., Pujol-Jover, M., Juan, C., Gázquez-Abad \& Alejandro, A. (2018). An extension of the technology acceptance model for online learning environments, Interactive Learning Environments, 26(7), 895-910. doi:10.1080/10494820.2017.1421560

Ministry of Administrative Reconstruction. (2019). National Action plan for Digital Skills and Jobs in Greece. Retrieved from https://www.nationalcoalition.gov.gr/wpcontent/uploads/2019/06/NC-Action-Plan-2019_EN-v5_272178237_signed.pdf

Fathema, N., \& Shannon, D. \& Ross, M. (2015). Expanding The Technology Acceptance Model (TAM) to Examine Faculty Use of Learning Management Systems (LMSs) In Higher Education Institutions. Journal of Online Learning and Teaching, 11(2). 210-233.

Fokides, E. (2017). Pre-service teachers' intention to use MUVEs as practitioners - A structural equation modelling approach. Journal of Information Technology Education: Research, 16, 47-68.

Fokides, E., Atsikpasi, P., Kaimara, P., \& Deliyannis, I. (2019). Factors influencing the subjective learn-ing effectiveness of serious games. Journal of Information Technology Education: Research, 18, 437-466. doi:10.28945/4441

Giannakos, M. (2013). Enjoy and learn with educational games: Examining factors affecting learning performance. Computers \& Education, 68, 429-439. doi:10.1016/j.compedu.2013.06.005

Hamari, J., \& Koivisto, J. (2013). Social motivations to use gamification: an empirical study of gamifying exercise. Proceedings of the 21st European Conference on Information Systems, Utrecht, Netherlands

Hamari, J., Koivisto, J., \& Sarsa, H. (2014). Does Gamification Work? -- A Literature Review of Empirical Studies on Gamification. Proceedings of the 47th Hawaii International Conference on System Sciences. doi:10.1109/hicss.2014.377

Herzig, P., Strahringer, S., \& Ameling, M. (2012). Gamification of ERP systems Exploring gamification effects on user acceptance constructs.Multikonferenz Wirtschaftsinformatik 2012 - Tagungsband der MKWI 2012, 793-804.

Hu, P. J., \& Hui, W. (2011) Is Technology-Mediated Learning Made Equal for All? Examining the Influences of Gender and Learning Style. In: Teo T. (eds) Technology Acceptance in Education. SensePublishers. doi:10.1007/978-94-6091487-4_6

Kim, H., Hong, A., \& Song, H.-D. (2018). The Relationships of Family, Perceived Digital Competence and Attitude, and Learning Agility in Sustainable Student Engagement in Higher Education. Sustainability, 10(12), 4635. doi: $10.3390 /$ su10124635

Koivisto, J., \& Hamari, J. (2019). The rise of motivational information systems: A review of gamification research. International Journal of Information Management, 45, 191210. doi:10.1016/j.ijinfomgt.2018.10.013 
Krasna, M., \& Bratina, T (2010). Universal digital competences. Proceedings of the 21st Central European Conference on Information and Intelligent Systems CECIIS 2010, Varazdin, Croatia.

Krašna, M., \& Bratina, T. (2012). Designing digital security course in educational sciences. International Journal of Knowledge Engineering and Soft Data Paradigms, 3(3/4), 280. doi:10.1504/ijkesdp.2012.050723

Liu, I., Chen, M., Sun, Y., Wible, D., \& Kuo, C. (2010). Extending the TAM model to explore the factors that affect the Intention to Use an Online Learning Community. Computers $\mathcal{E}$ Education, 54(2), 600-610. doi:10.1016/j.compedu.2009.09.009

Mac Callum, K., Jeffrey, L., \& NA, K. (2014). Factors Impacting Teachers' Adoption of Mobile Learning. Journal of Information Technology Education: Research, 13, 141162. doi:10.28945/1970

Moghavvemi, S. (2015). Impact of Perceived Self-Efficacy and Capability to Use IT Innovation on Individual Use Behaviour. SSRN Electronic Journal. doi:10.2139/ssrn.256173

Nikolaidis, S., Nath, S., Procaccia, A., \& Srinivasa, A. (2017). Game-Theoretic Modeling of Human Adaptation in Human-Robot Collaboration. Proceedings of the 2017 ACM/IEEE International Conference on Human-Robot Interaction. doi:10.1145/2909824.3020253

Oluwajana, D., Vanduhe, V., Idowu, A., Cemal Nat, M., \& Fadiya, S. (2019). The Adoption of Students' Hedonic Motivation System Model to Gamified Learning Environment. Educational Technology \& Society, 17(3), 291-307. doi:10.4067/S0718-18762019000300109outcomes

Panagiotarou, A., Vassiliadis, B., \& Kameas, A. (2019). A Certification Framework for managing digital skills according to DIGCOMP2.1. Proceedings of New Perspectives in Education 8th edition. Firenze: Pixel.

Panagiotarou, A., \& Stamatiou, Y. C. (2019). Training Offers in Greece Fostering eCompetencies. International Journal of Learning, Teaching and Educational Research, 18(7), 214-227. doi:10.26803/ijlter.18.7.14

Prudon, P. (2015). Confirmatory Factor Analysis as a Tool in Research Using Questionnaires: A Critique. Comprehensive Psychology, 4, 03.CP.4.10. doi:10.2466/03.cp.4.10

Rajabalee, B. Y., Santally, M. I., \& Rennie, F. (2019). A study of the relationship between students' engagement and their academic performances in an eLearning environment. E-Learning and Digital Media, 17(1), 1-20. doi: $10.1177 / 2042753019882567$

Sánchez-Mena, A., Martí-Parreño, J., \& Aldás-Manzano, J. (2018). Teachers' intention to use educational video games: The moderating role of gender and age. Innovations in Education and Teaching International, 56(3), 318-329. doi:10.1080/14703297.2018.1433547

Schlag, M., \& Imhof, M. (2017). Does Perceived Ease of Use Mitigate Computer Anxiety and Stimulate Self-regulated Learning for Pre-Service Teacher Students? International Journal Of Higher Education, 6(3), 154. doi: 10.5430/ijhe.v6n3p154

Serdyukov, P. (2017). Innovation in education: what works, what doesn't, and what to do about it? Journal of Research in Innovative Teaching \& Learning, 10(1), 4-33. doi:10.1108/jrit-10-2016-0007

Spyropoulou, N., Pierrakeas, C. J., \& Kameas, A. (2019). Experience Gained From Applying a Team-Based Approach for MOOC Development. International Journal of Web-Based Learning and Teaching Technologies (IJWLTT), 14(2), 15-30. doi:10.4018/IJWLTT.2019040102 
Stiles-Shields, C., Montague, E., Lattie, E. G., Schueller, S. M., Kwasny, M. J., \& Mohr, D. C. (2017). Exploring User Learnability and Learning Performance in an App for Depression: Usability Study. JMIR Human Factors, 4(3), e18. doi:10.2196/humanfactors.7951

Stephan, M., Markus, S., \& Gläser-Zikuda, M. (2019). Students' Achievement Emotions and Online Learning in Teacher Education. Frontiers In Education, 4. doi:10.3389/feduc.2019.00109

Tan, P. J. B., \& Hsu, M. (2018). Designing a System for English Evaluation and Teaching Devices: A PZB and TAM Model Analysis. Eurasia Journal of Mathematics, Science and Technology Education, 14(6), 2107-2119. https://doi.org/10.29333/ejmste/86467

Tarhini, A., Hone, K., \& Liu, X. (2013). Factors Affecting Students' Acceptance of eLearning Environments in Developing Countries:A Structural Equation Modeling Approach. International Journal of Information and Education Technology, 54-59. doi:10.7763/ijiet.2013.v3.233.

Unesco (2017). Working Group on Education: digital skills for life and work. Retrieved from https://unesdoc.unesco.org/ark:/48223/pf0000259013

Varannai, I., Sasvari, P., \& Urbanovics, A. (2017). The Use of Gamification in Higher Education: An Empirical Study. International Journal of Advanced Computer Science and Applications, 8(10). doi:10.14569/ijacsa.2017.081001

Venkatesh, Thong, \& Xu. (2012). Consumer Acceptance and Use of Information Technology: Extending the Unified Theory of Acceptance and Use of Technology. MIS Quarterly, 36(1), 157. doi:10.2307/41410412

Venkatesh, V., \& Davis, F. D. (2000). A theoretical extension of the technology acceptance model: Four longitudinal field studies. Management Science, 46 (2) 186-204, doi:10.1287/mnsc.46.2.186.11926

Venkatesh, V., Morris, M. G., Davis, G. B., \& Davis, F. D. (2003). User Acceptance of Information Technology: Toward a Unified View. MIS Quarterly, 27(3), 425. doi: $10.2307 / 30036540$

Venkatesh, V., \& Bala, H. (2008). Technology Acceptance Model 3 and a Research Agenda on Interventions. Decision Sciences, 39(2), 273-315. doi:10.1111/j.15405915.2008.00192.x

Vlachopoulos, D., \& Makri, A. (2017). The effect of games and simulations on higher education: a systematic literature review. International Journal of Educational Technology in Higher Education, 14(1). doi:10.1186/s41239-017-0062-1

Wang, H., \& Sun, C.-T. (2012). Game Reward Systems: Gaming Experiences and Social Meanings. Proceedings of DiGRA 2011 Conference: Think Design Play.

Woo, J. C. (2014). Digital game-based learning supports student motivation, cognitive success, and performance Educational Technology \& Society, 17(3), 291-307.

$\mathrm{Wu}, \mathrm{B} .$, \& Chen, X. (2017). Continuance intention to use MOOCs: Integrating the technology acceptance model (TAM) and task technology fit (TTF) model. Computers in Human Behavior, 67, 221-232. doi:10.1016/j.chb.2016.10.028

\author{
Acronyms \\ PU: Perceived Usefulness \\ PEOU: Perceived Ease of Use \\ ICT: Information and Communication Technology \\ ICT Level: Measure the digital skill's Level \\ PSE: Perceived Self-Efficacy \\ PL: Perceived Learnability \\ FUN: Fun and Reward
}

